\title{
1,5-Dichloroethanoanthracene Derivatives as Antidepressant Maprotiline Analogues: Synthesis and DFT Computational Calculations
}

\author{
Mujeeb Sultan ( Alhosami1983@yahoo.co.uk) \\ King Saud University \\ Renjith Raveendran Pillai \\ Central Polytechnic \\ Eman Alzahrani \\ Taif university
}

\section{Research Article}

Keywords: 1,5-dichloroethanoanthracene, Diels-Alder reaction, Wittig reaction, olefinic hydrogenation, maprotiline analogue, DFT

Posted Date: May 17th, 2021

DOl: https://doi.org/10.21203/rs.3.rs-515953/v1

License: (c) (i) This work is licensed under a Creative Commons Attribution 4.0 International License. Read Full License 


\section{Abstract}

The chlorinated tetracyclic 1,5-dichloro-9,10-dihydro-9,10-ethanoanthracen-12-yl)-N-methylmethanamine 1, a maprotiline analogue, has been synthesized via reduction and Diels-Alder reaction followed by reductive amination of Aldehyde 2 . Density Functional Theory calculations were performed to identify the possible isomers of the intermediate compound aldehyde $\mathbf{2}$, these calculations were in a good agreement with experimental result where aldehyde $\mathbf{2}$ could exist in three isomers with comparable energies. In addition, the side chain of this aldehyde 2 was extended via Wittig reaction to obtain the unsaturated ester 5 that subjected to selective olefinic catalytic hydrogenation to obtain the corresponding saturated ester 6. 1D-NMR (DEPT) and 2D-NMR (HSQC, DQF-COSY) techniques were recruited for structural elucidation in addition to HRMS.

\section{Introduction}

anthracenes are simply and efficiently incorporated into several organic reaction and proved to have a wide range of industrial applications such as in fluorescent sensor [1, 2], laser dyes [3] and supramolecular assemblies [4,5]. Their application in the pharmaceutical agents is another interesting field.

From the organic synthesis point of view, 1,5-dichloroanthracene was functionalized through Kumada coupling to access a series of 1,5- functionalized anthracenes [6]. Based on 1,5-dichloroanthracene, many macrocyclic compounds have been synthesized and reported in the literatures [7-9]. 1,5dichloroanthracene was allowed to react with 3-chlorobenzyne through Diels-Alder (DA) reaction to access substituted triptycene derivatives $[10,11]$. Starting from 1,5-dichloroanthracene and another anthracenes, a series of SiMe3-functionalized anthracene derivatives was synthesized via multistep cross coupling reactions and NMR-qualitatively studied towards UV irradiation [12].

From biological point of view; 1,5-dichloroanthracene itself shows antioxidant activities through a proton transfer mechanism [13]. A variety of 1,5-dichloroanthracene- and anthraquinone-related derivatives proved to possess an anti-inflammatory activity with no significant cytotoxicity in human neutrophils [14] another anthracene analogues displayed potent anti-inflammatory activity against superoxide anion production and induced apoptosis, thus exerting antitumor activity [15].

1,5-dichloroethanoanthracene derivatives are related in structure to the antidepressant drug maprotiline 9,10-dihydro-N-methyl-9,10-ethanoanthracene-9-propanamine (Fig. 1), which exhibit in vitro antiproliferative activity against Burkitts Lymphoma (BL) cell lines DG-75 [16] and induce anti-multi-drug resistance (MDR) effect in the cancer cell lines and plasmodium falciparum [17] as well 1,5dichloroethanoanthracene derivatives are related in structure to benzoctamine 9,10-dihydro-9(methylaminomethyl)-9,10-ethanoanthracene (Fig. 1) that have been used to treat an anxiety and tension [18]. 
Designing and synthesis of new 1,5-dichloroethanoanthracene derivatives is not straightforward and considered as imperative challenges, that more than one isomer will be obtained in the first step of 1,5dichloroanthracene functionalization. However we were delighted to synthesis 1,5dichloroethanoanthracenes $(1,2,5,6)$ and discover their structures through using different spectroscopy techniques including 2D-NMR. In addition computational calculations were performed in order to identify the possible isomers of the aldehyde 1,5-dichloroethanoanthracene 2 .

\section{Experimental}

\section{Chemistry protocols}

Most of the reagents and solvents were of analytical grade. Starting chemicals were purchased from Aldrich (Merck). Perkin Elmer 240 elemental analyzer was used to obtain infra-red (IR) spectrum. ${ }^{1} \mathrm{H}$ and

${ }^{13} \mathrm{C}$-NMR spectra were recorded on either Joel $400 \mathrm{MHz}$ or Bruker $500 \mathrm{MHz}$. Mass spectra (MS) and high resolution mass spectra (HRMS) data were obtained on a Q-Tof Premier UPLC-MS. Reactions were monitored using thin-layer chromatography (TLC) plates (Merck, Germany), stained with valine and then spots were detected with $254 \mathrm{~nm}$ UV lamp. Silica gel (35-70 mesh) was employed in column chromatography purification.

\section{Synthesis}

Synthesis of 1,5-Dichloroanthracene $3[26,6]$

1,5-Dichloroanthraquinone 4 (10.0 g, $36.1 \mathrm{mmol})$ and Zinc dust $(50.0 \mathrm{~g}, 765 \mathrm{mmol})$ were suspended in $200 \mathrm{~mL}$ of aqueous $28 \% \mathrm{NH}_{3}$ with stirring for $3 \mathrm{~h}$ at $100{ }^{\circ} \mathrm{C}$. After cooling to r.t., the reaction mixture was separated by filtration and the filtrate was eluted and extracted several times with $\mathrm{CH}_{2} \mathrm{Cl}_{2}$. The $\mathrm{CH}_{2} \mathrm{Cl}_{2}$ organic phases were collected, dried over $\mathrm{MgSO}_{4}$, filtered and concentrated under vacuum. To the residual crude, $500 \mathrm{~mL}$ isopropanol and $50 \mathrm{~mL}$ aqueous $\mathrm{HC} 1$ (12 M) were added. After refluxing the reaction mixture for $3 \mathrm{~h}$, the mixture was cooled, concentrated in vacuo and then partitioned between $\mathrm{CH}_{2} \mathrm{Cl}_{2}$ and aqueous $5 \% \mathrm{NaHCO}_{3}$. The $\mathrm{CH}_{2} \mathrm{Cl}_{2}$ organic phase was collected, dried with $\mathrm{MgSO}_{4}$, filtered and concentrated to give crude 1,5-dichloroanthracene 3 . This crude was crystallized using a $\mathrm{CH}_{2} \mathrm{Cl}_{2}$ Petroleum ether mixture. The product 1,5-dichloroanthracene 3 was dried in the air for $24 \mathrm{~h}(7.5 \mathrm{~g}, 30.49$ $\mathrm{mmol}$ ) as yellow-orange needles in a $84.45 \%$ yield; $\mathrm{mp} 187-188^{\circ} \mathrm{C}$; IR (KBr): $\mathrm{u}=681,720,736,778,849$,

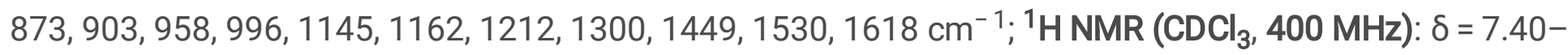
$7.61(\mathrm{~m}, 4 \mathrm{H}, \mathrm{ArH}), 8.00$ (dd; $j=2.92 \mathrm{~Hz}, 2 \mathrm{H}, \mathrm{ArH}), 8.42(\mathrm{~s}, 1 \mathrm{H}, \mathrm{ArH}), 8.84(\mathrm{~s}, 1 \mathrm{H}, \mathrm{ArH}) \mathrm{ppm} .{ }^{13} \mathrm{C} \mathrm{NMR}$ $(\mathrm{CDCl} 3,100 \mathrm{MHz}): \delta=124.37,125.42,125.58,126.29,128.24,131.7,132.8 \mathrm{ppm}$.

Synthesis of 1,5-dichloro-9,10-dihydro-9,10-ethanoanthracene-12-carbaldehyde 2 at - $15^{\circ} \mathrm{C}$

Into a previously $-15{ }^{\circ} \mathrm{C}$ cooled solution of 1,8-dichlorolanthracene $3\left(500 \mathrm{mg}, 2 \mathrm{mmol}\right.$ ) in $70 \mathrm{~mL} \mathrm{CH}_{2} \mathrm{Cl}_{2}$, acrolein $(0.65 \mathrm{~mL}, 9.3 \mathrm{mmol})$ was added. Then, $\mathrm{BF}_{3} \cdot \mathrm{OEt}_{2}(0.5 \mathrm{~mL}, 4.05 \mathrm{mmol})$ was drop wisely added and 
the mixture was allowed to stir at $-15{ }^{0} \mathrm{C}$ for 1 hour then at room temperature for 4 hours. The reaction was then quenched with sat. $\mathrm{NaCl}$ and extracted with $\mathrm{CH}_{2} \mathrm{Cl}_{2}$. The organic layers were collected, dried with $\mathrm{Na}_{2} \mathrm{SO}_{4}$, filtered and concentrated. The crude product was preliminary purified by column chromatography on silica gel using dichloromethane -petroleum ether (1:1) to afford aldehyde 3 (450 mg, $1.49 \mathrm{mmol}$ ) as three isomeric adducts in a $74 \%$ yield; $\mathrm{IR}(\mathrm{KBr}): \mathrm{v}=576,706,775,1169,1264,1458,1570$, $1723,2961,3024,3047 \mathrm{~cm}^{-1}$. A mixture of isomeric adducts (300 mg, $1 \mathrm{mmol}$ ) was separated by column chromatography on silica gel (1:1-Hexane: toluene) to give the initially eluted two isomers of 2 (2a) (160 $\mathrm{mg}, 0.53 \mathrm{mmol})$ as yellow viscous with the following characteristics; ${ }^{1} \mathrm{H} \mathrm{NMR}\left(\mathrm{CDCl}_{3}, 400 \mathrm{MHz}\right): \delta=$ 1.93-2.04 (m, 2H, H-C11), 2.14-2.22(m, 2H, H-C11), 2.8-2.89 (m, 2H, H-C12), 4.93 (pent, J = 2.74 Hz, 2H H-C10), 5.26 (dd, J = 7.2, 2.45 Hz, 2H, H-C9), 7.1-7.47 (m, 12H, H-Ar), 9.52 (d, J = 0.8, 1H, H-CHO), 9.56 (d, $\mathrm{J}=0.8,1 \mathrm{H}-\mathrm{CHO}) \mathrm{ppm} .{ }^{13} \mathrm{C} \mathrm{NMR}(\mathrm{CDCl} 3,100 \mathrm{MHz}): \delta=27.29,27.32,40.37,41.50,41.59,49.87,51.07$, $122.45,122.48,122.56,123.54,123.77,126.78,127.11,127.17,127.24,127.28,127.50,127.78,129.35$, $123.38,129.57,130.23,136.58,138.98,140.61,140.79,140.94,143.25,145.08,145.37,200.91,201.17$ ppm. and a pure isomer of $2(2 \mathrm{~b})(140 \mathrm{mg}, 0.46 \mathrm{mmol})$ as white solid with the following characteristics; ${ }^{1} \mathrm{H}$ NMR $\left(\mathrm{CDCl}_{3}, 400 \mathrm{MHz}\right): \delta=1.99-2.06(\mathrm{~m}, 1 \mathrm{H}, \mathrm{H}-\mathrm{C} 11), 2.11-2.18(\mathrm{~m}, 1 \mathrm{H}, \mathrm{H}-\mathrm{C} 11), 2.77-2.84(\mathrm{~m}, 1 \mathrm{H}, \mathrm{H}-$ C12), 4.44 (t, J = 0.8 Hz, 1H, H-C10), 4.72 (d, J = 0.8 Hz, 1H, H-C9), 7.21-7.45 (m, 6H, H-Ar), 9.45 (d, J = 0.8, $1 \mathrm{H}, \mathrm{H}-\mathrm{CHO}) \mathrm{ppm} .{ }^{13} \mathrm{C}$ NMR (CDCl3, $\left.100 \mathrm{MHz}\right): \delta=28.76,43.69,45.20,51.22,123.45,123.51,123.64$, $124.53,125.96,125.99,126.28,126.55,139.37,142.12,143.79,144.06,202.73$ ppm.

Synthesis of 1,5-dichloro-9,10-dihydro-9,10-ethanoanthracen-12-yl)-N-methylmethanamine 1 [27]

To a $50 \mathrm{~mL}$ two-neck round-bottom flask connected to a condenser capped with a $\mathrm{H}_{2}$ balloon and a rubber septum, a $100 \mathrm{mg} \mathrm{Pd}-\mathrm{C}$ catalyst was added. The flask was evacuated and backfilled with $\mathrm{H}_{2}$ two times. Then a solution of aldehyde $2(50 \mathrm{mg}, 0.165 \mathrm{mmol})$ in methanol $(3 \mathrm{~mL})$ and $(0.25 \mathrm{~mL}, 2 \mathrm{M})$ of methylamine solution in methanol were added into flask by syringe through septum. After $1.5 \mathrm{~h}$ of the reaction time, the reaction mixture was filtered and washed with $\mathrm{CH}_{2} \mathrm{Cl}_{2}$, then removed the solvent to afford the amine 1 with the following characteristics: IR (KBr): $v=706,740,1266,1422,2987,3055 \mathrm{~cm}^{-1}$, ${ }^{1} \mathrm{H} \mathrm{NMR}\left(\mathrm{CDCl}_{3}, 500 \mathrm{MHz}\right): \delta=1.25-1.28(\mathrm{~m}, 1 \mathrm{H}, \mathrm{H}-\mathrm{C} 11), 1.95-2.11(\mathrm{~m}, 1 \mathrm{H}, \mathrm{H}-\mathrm{C} 11), 2.25-2.29(\mathrm{~m}, 2 \mathrm{H}, \mathrm{H}-$ $\left.\mathrm{C} 12, \mathrm{H}_{-}-\mathrm{Cl}^{\prime}, \mathrm{CH}_{2}\right), 2.32\left(\mathrm{~s}, 3 \mathrm{H}, \mathrm{H}-\mathrm{CH}_{3}\right), 2.43-2.47\left(\mathrm{~m}, 1 \mathrm{H}, \mathrm{H}-\mathrm{Cl}^{\prime}, \mathrm{CH}_{2}\right), 4.29$ (t, J = 2.12, 1H, H-C10), 4.47 (d, J $=1.64,1 \mathrm{H}, \mathrm{H}-\mathrm{C} 9), 7.07-7.17(\mathrm{~m}, 3 \mathrm{H}, \mathrm{Ar}-\mathrm{H}), 7.19-7.46(\mathrm{~m}, 3 \mathrm{H}, \mathrm{Ar}-\mathrm{H})$ ppm; DEPT 90: $35.80(\uparrow \mathrm{CH}), 43.73$ (CH), $46.05(\uparrow C H)$; DEPT 135: $33.02\left(\downarrow \mathrm{CH}_{2}\right), 33.39\left(\uparrow \mathrm{CH}_{3}\right), 35.80(\uparrow \mathrm{CH}), 43.73(\uparrow \mathrm{CH}), 46.05(\uparrow \mathrm{CH}), 54.31$ $\left(\downarrow \mathrm{CH}_{2}\right)$ ppm; MS (ES) m/z (\%) = 318 (100) [M+], 284 (70), 250 (18), 184 (40), 117 (62), 85 (40); HRMS (ES) Calcd for $\mathrm{C}_{18} \mathrm{H}_{18} \mathrm{NCl}_{2}\left[\mathrm{M}^{+}\right]$318.0816, Found 318.0815.

Synthesis of Z/E-Ethyl 3-(1,5-dichloro-9,10-dihydro-9,10-ethanoanthracen-12-yl)propenoate 5

Into a $50-\mathrm{mL}$ round-bottomed flask containing aldehyde $2(755 \mathrm{mg}, 2.5 \mathrm{mmol})$ pre-dissolved in a $15 \mathrm{~mL}$ dichloromethane, a two equivalent Wittig reagent (Carbethoxymethylene)triphenylphosphorane (174 mg, $5 \mathrm{mmol}$ ) was added. The reaction mixture was stirred overnight at room temperature, then solvent was 
removed to purify via silica gel column chromatography using the eluent system (Ethyl acetate/Petroleum ether, 1:20) affording unsaturated ester 5 as Z/E isomer (700 mg, $1.9 \mathrm{mmol}, 76 \%)$ in ratio of $1: 3.5$ respectively as yellow oil with the following characteristics; $I R(K B r): ~ U=650,735,909$, $1036,1097,1170,1240,1271,1305,1369,1461,1650,1709,2254,2875,2971,3537 \mathrm{~cm}^{-1} ;{ }^{1} \mathrm{H}$ NMR $\left(\mathrm{CDCl}_{3}, 400 \mathrm{MHz}\right): \delta=1.15-1.35\left(\mathrm{~m}, 6 \mathrm{H}, \mathrm{H}-\mathrm{CH}_{3}(\mathrm{Z} / \mathrm{E})\right), 1.45-1.52(\mathrm{~m}, 1 \mathrm{H}, \mathrm{H}-11), 2.07-2.12(\mathrm{~m}, 1 \mathrm{H}, \mathrm{H}-11)$, 2.73-2.80 (m, 1H, H-12), 4.12-4.18 (q, J = 25, 2H, ), $4.22(\mathrm{~d}, \mathrm{~J}=5,1 \mathrm{H}, \mathrm{H}-9), 4.26(\mathrm{q}, \mathrm{J}=25,2 \mathrm{H}$, ), $4.34(\mathrm{t}, \mathrm{J}$ $=3,1 \mathrm{H}, \mathrm{H}-10), 4.35(\mathrm{t}, \mathrm{J}=2,1 \mathrm{H}, \mathrm{H}-10), 5.78(\mathrm{~d}, \mathrm{~J}=25 \mathrm{~Hz}, 1 \mathrm{H}),, 6.45(\mathrm{dd}, \mathrm{J}=15,5,1 \mathrm{H}),, 7.1-7.19(\mathrm{~m}, 6 \mathrm{H}$, $\mathrm{Ar}-\mathrm{H}), 7.25-7.35(\mathrm{~m}, 6 \mathrm{H}, \mathrm{Ar}-\mathrm{H})$ ppm. For only $(E) \mathrm{HSQC}$ and ${ }^{13} \mathrm{C} \mathrm{NMR}\left(\mathrm{CDCl}_{3}, 100 \mathrm{MHz}\right): \delta=14,33.9\left(\mathrm{CH}_{3}\right)$, 43 ( $\left.\mathrm{CH}_{2}, \mathrm{C} 11\right), 40.09$ (C12), 43 (C10), 48 (C9), 59.8 (-O- $\left.\mathrm{CH}_{2}-\right), 120.7,122.9,123.2,123.5,125.03,125.06$, $125.08,125.1,134,139.5,143.4,143.6,143.9,152,167$ ppm; HRMS (ES) Calcd for $\mathrm{C}_{21} \mathrm{H}_{18} \mathrm{O}_{2} \mathrm{Cl}_{2} \mathrm{Na}[\mathrm{M}+]$ 395.0582, Found 395.0576.

Synthesis of Ethyl 3-(1,5-dichloro-9,10-dihydro-9,10-ethanoanthracen-12-yl)propanoate 6

Two-necked round-bottom flask containing Pd/C (70 mg, 10\%) was wetted with ethanol. After evacuation and charging flask with hydrogen $\left(\mathrm{H}_{2}\right.$, balloon) two times, a solution of unsaturated ester $\mathbf{5}(820 \mathrm{mg}, 2.2$ $\mathrm{mmol}$ ) in $15 \mathrm{ml}$ ethanol was added. The mixture was stirred overnight at room temperature under $\mathrm{H}_{2}$, then filtered through celite with $\mathrm{CH}_{2} \mathrm{Cl}_{2}$. The solvent was removed in vacuo to give the saturated ester $\mathbf{6}$ (350 $\mathrm{mg}, 0.93 \mathrm{mmol}, 42 \%)$ as yellow oil with the following characteristics; ${ }^{1} \mathrm{H} \mathrm{NMR}\left(\mathrm{CDCl}_{3}, 400 \mathrm{MHz}\right): \delta=$ 1.15-1.2 (m, 1H, H-C11), 1.21-1.30 (m, 4H; $\left.1 \mathrm{H}-\mathrm{C}^{\prime} / 1,3 \mathrm{H}, \mathrm{H}-\mathrm{CH}_{3}\right), 1.47-1.56\left(\mathrm{~m}, 1 \mathrm{H}, \mathrm{H}-\mathrm{C}^{\prime} 1\right.$ ), $1.87-1.95(\mathrm{~m}$, 1H, H-C12), 2-2.12 (m, 1H, H-C11), 2.33 (t, J = 12, 2H, H-C/2), 4.08 (q, J = $\left.10 \mathrm{~Hz}, 2 \mathrm{H},-0-\mathrm{CH}_{2}-\right), 4.15$ (d, J = 0.4 $\mathrm{Hz}, 1 \mathrm{H}, \mathrm{H}-\mathrm{C} 9), 4.26(\mathrm{t}, \mathrm{J}=2 \mathrm{~Hz}, 1 \mathrm{H}, \mathrm{H}-\mathrm{C} 10), 7.1-7.20$ (m, 3H, Ar-H), 7.25-7.35 (m, 3H, Ar-H) ppm; HSQC $\left(\mathrm{CDCl}_{3}, 100 \mathrm{MHz}\right): \delta=14,30.05\left(\mathrm{CH}_{3}\right), 30.05\left(\mathrm{CH}_{2}, \mathrm{C}^{\prime} 2\right), 31.15\left(\mathrm{CH}_{2}, \mathrm{C}^{\prime} 1\right), 34\left(\mathrm{CH}_{2}, \mathrm{C} 11\right), 38$ (C10), $49(\mathrm{C} 9)$, $60\left(\mathrm{CH}_{2},-\mathrm{O}-\mathrm{CH}_{2}-\right)$ ppm; HRMS (ES) Calcd for $\mathrm{C}_{21} \mathrm{H}_{20} \mathrm{O}_{2} \mathrm{Cl}_{2} \mathrm{Na}\left[\mathrm{M}^{+}\right]$397.0738, Found 397.0735.

\section{Computational Details}

Density Functional Theory (DFT) calculations were performed using Gaussian 09 software [28] for identifying the possible conformers of the compound 2. A hybrid, non-local exchange and correlation functional of Becke-Lee, Parr, Yang (B3LYP) [29] has been used with the 6-311G (d, p) for DFT calculations. The lowest energy conformers have been obtained by detailed conformation search employing potential energy scan method.

\section{Results And Discussions}

\section{Retrosynthetic Analysis and Strategy for Chlorinated Maprotiline Analogue 1}

We began the synthesis with the intention of obtaining the products efficiently in high yields, lowering the number of steps, high level of selectivity, high level of atom economy, environmentally friendly and at a low cost. Our retrosynthetic breakdown of our target chlorinated maprotiline analogue 1 afford two fragments; the tetracyclic intermediate with its bridged dihydroethanoanthracene system I and 
anthracene precursor 3. (Scheme 1). The target compound 1 could be obtained by functional group interconversion ( $\mathrm{FGI}$ ) of the key intermediate 2 . The key intermediate $\mathbf{2}$ with its system [2.2.2] could be built in one-step via a DA reaction between a suitable dienophile possessing functional group and the 1,5dichloroanthracene $\mathbf{3}$ center ring as a diene. Acrolein is a reactive dienophile in Diels-Alder reaction and its reaction with 1,5-dichloroanthracene $\mathbf{3}$ could lead to the aldehyde functionality, which allow us to access other functional groups via FGI including our target amine 1. The preparation of the precursor $\mathbf{3}$ can be prepared from a commercial available 1,5-dichloroanthraquinone 4 , as described in the literature [6]

\section{Synthesis of the Chlorinated Maprotiline Analogue 1}

The target compound 1 was obtained according to the synthetic pathway (Scheme 2). The intermediate 1,5-dichloro-9,10-dihydro-9,10-ethanoanthracene-12-carbaldehyde 2 was prepared by $\mathrm{HCl}$-catalyzed reduction of 1,5-dichloroanthraquinone $\mathbf{4}$ followed by DA reaction of 1,5-dichloroanthracene $\mathbf{3}$ with acrolein. In fact, attempts to react 1,5-dichloroanthracene $\mathbf{3}$ with acrolein to yield aldehyde $\mathbf{2}$ under variety of conditions were not successful. TLC monitoring of these attempts reactions showed that a substantial amount of starting materials remained unreacted, this may refer to the presence of chlorine atoms on anthracene that render it a poor electron-donating diene. Then 1,5-dichloroanthracene $\mathbf{3}$ was allowed to react with acrolein using boron trifluoride etherate $\left(\mathrm{BF}_{3} \cdot \mathrm{OEt}_{2}\right)$ as catalyst, at room temperature as well at $-15^{\circ} \mathrm{C}$ to afford compound 2 but as three isomers in a ratio 1:1:1.75 as deduced from ${ }^{1} \mathrm{H}$-NMR spectrum (Fig. S1). IR spectrum supported the structure of the compound $\mathbf{2}$ and showed stretching vibration of the carbonyl group (CHO) as a strong peak at $1723 \mathrm{~cm}^{-1}$ (Fig. S2). Theoretically, the compound 2 could exist in more than one isomer and conformer forms, due to its stereocenters and spatial arrangement of $\mathrm{CHO}$ group regarding benzene rings. Computational calculations were in the same line, where three conformers were identified as presented in Table 2 and Fig. 2. Different solvent systems were recruited to purify these isomers, the hexane: toluene (1:1) mixture was the best one. Unfortunately, the three isomers of the aldehyde $\mathbf{2}$ could not be separated individually, that we haven't chiral columns. However, after several trials of normal column chromatography, the two isomers (called $\mathbf{2 a}$ ) were initially eluted together (Fig.

S3a, Fig. S4) while the third isomer (called $\mathbf{2 b}$ ) was purely separated alone (Fig. S3b, Fig. S5, Fig. S6). The protons of $\mathrm{CHO}$ group of the aldehyde $2 \mathrm{a}$ appeared separately as doublet signals at $\delta 952$ and $9.56 \mathrm{ppm}$ with coupling constant $\mathrm{J} 0.8 \mathrm{~Hz}$ for each, whereas the signals of bridgehead protons appeared collectively; since the signal of the protons integrated for carbon 10 (C10) appeared as pentet at $\delta 4.93$ ppm with coupling constant $\mathrm{J} 2.74 \mathrm{~Hz}$ and the signal of the protons integrated for carbon 9 (C9) appeared as double doublet at $\delta 5.26$ ppm with coupling constant J 7.2 and $2.45 \mathrm{~Hz}$ (Fig. S3c).

The ${ }^{1} \mathrm{H}$ and ${ }^{13} \mathrm{C}$ spectra of the isomer $\mathbf{2} \mathbf{b}$ can be divided into two regions; aromatic and aliphatic (Fig. S5, Fig. S6). In the aromatic region a multiple region at $\delta 7.21-7.45 \mathrm{ppm}$ assigned for the protons integrated for anthracene rings and this region exhibited in ${ }^{13} \mathrm{C}$ spectrum as peaks at $\delta 123.45-144.06 \mathrm{ppm}$. In the aliphatic portion, there are a triplet signal at $\delta 4.44 \mathrm{ppm}$ with a coupling constant $\mathrm{J} 0.8 \mathrm{~Hz}$ assigned for the protons integrated for carbon 10 (C10) and doublet signal $\delta 4.72 \mathrm{ppm}$ with a coupling constant $\mathrm{J} 0.8$ $\mathrm{Hz}$ assigned for the protons integrated for carbon 9 (C9). These signals are corresponding to the peaks 
appeared at $\delta 43.69$ and $45.20 \mathrm{ppm}$ in ${ }^{13} \mathrm{C}$ spectrum respectively; these signals are considered one of the two markers indicating for DA cycloaddition adduct $\mathbf{2 b}$ (Fig. S5b). The multiplet signals appeared at $\delta$ $1.99-2.06,2.11-2.18 \mathrm{ppm}$ are assigned to the protons of carbon 11 (C11) that appeared at $\delta 28.76 \mathrm{ppm}$ in ${ }^{13} \mathrm{C}$ spectrum and the ${ }^{1} \mathrm{H}$ multiplet signal that appeared $\delta 2.77-2.84 \mathrm{ppm}$ is assigned to the proton of carbon 12 (C12) that appeared at $\delta 51.22 \mathrm{ppm}$ in ${ }^{13} \mathrm{C}$ spectrum. The aldehyde signal is considered the second marker indicating for DA cycloaddition adduct $\mathbf{2 b}$, this signal represents for the only aldehyde proton in the expected structure $2 \mathrm{~b}$ and appeared as a doublet at $\delta 9.45 \mathrm{ppm}$ with a coupling constant $\mathrm{J}$ $0.8 \mathrm{~Hz}$ as well as ${ }^{13} \mathrm{C}$-NMR confirms the existence of aldehyde group (CHO) as a single peak at $\delta 202.73$ ppm

Reductive amination of the aldehyde 2 using a combination of a commercially available solution of methylamine in methanol, molecular hydrogen and $\mathrm{Pd}-\mathrm{C}$ afforded the target amine 1 . Generally, the two commonly used reductive amination protocols are based on either catalytic hydrogenation or hydride reducing agents; in contrast to hydride reducing agents, the use of molecular hydrogen is economically attractive [19-24]. The ${ }^{1} \mathrm{H}$ and ${ }^{13} \mathrm{C}$ NMR analysis of the target amine 1 is similar to its precursor $\mathbf{2}$ with slight differences but the signal of $\mathrm{CHO}$ disappeared in amine 1 and IR supported this finding (Fig. 7), in addition to the appearance of singlet signal at $\delta 2.32 \mathrm{ppm}$ that assigned to the methyl protons $\left(-\mathrm{N}-\mathrm{CH}_{3}\right)$ and correspond to the peak at $\delta 33.39 \mathrm{ppm}$ in the ${ }^{13} \mathrm{C}$ NMR spectrum. For further structural elucidation of the target compound 1; Distortionless Enhancement by Polarization Transfer (DEPT) and Heteronuclear single quantum coherence spectroscopy (HSQC) were run and presented in the (Table 1, Fig. S8, Fig. S9, Fig. S10). It's well known that only $\mathrm{CH}$ groups appear as positive signals $(\uparrow \mathrm{CH})$ in the DEPT-90 spectrum, whereas in the DEPT-135 spectrum, $\mathrm{CH}_{3}$ and $\mathrm{CH}$ groups appear as positive signals $\left(\uparrow \mathrm{CH}, \uparrow \mathrm{CH}_{3}\right)$ but $\mathrm{CH}_{2}$ groups as negative signals $\left(\downarrow \mathrm{CH}_{2}\right)$. The DEPT-90 spectrum of amine 1 shows three positive signals $(\uparrow \mathrm{CH})$ at $\delta 35.80,43.73$ and 46.05 ppm assigned to $\mathrm{C} 12, \mathrm{C} 10$ and $\mathrm{C} 9$ respectively (Fig. S8). The DEPT-135 spectrum shows four positive signals and two negative signals; among of them three positive signals assigned to the three $\mathrm{CH}$ groups and the fourth positive one is assigned to the carbon of methyl group $\left(\mathrm{CH}_{3}\right)$ that appeared at $\delta 33.39 \mathrm{ppm}$, the two negative signals that appeared at $\delta 33.02$ and $54.31 \mathrm{ppm}$ are assigned to methylene groups (- $\left.\mathrm{CH}_{2}-\right)$ of $\mathrm{C} 11$ and $\mathrm{C} 1^{\prime}$ respectively (Fig. S9).

HSQC experiments permit to get high-quality spectra of the protons attached to a specific carbon. According to HSQC spectrum (Fig. S10), the structure of amine 1 is clearly elucidated and the $\mathrm{H}$ atoms that are attached to the carbon atoms as shown in the (Table 1). Interestingly, the tow protons assigned to $\mathrm{C} 11$ are appeared in separated regions; one of them is appeared at $\delta 1.25-1.28 \mathrm{ppm}$ as multiple signal, although, it appeared as overlapped triplet signal when enlarge this spectra region, and the other proton is appeared at $\delta 1.95-2.11 \mathrm{ppm}$ as multiple signal. 
Table 1

DEPT and HSQC results of the target amine 1

\begin{tabular}{|c|c|c|c|c|}
\hline \multirow[t]{3}{*}{ Carbon NO. } & \multicolumn{4}{|l|}{ Chemical shift $\delta$} \\
\hline & \multirow[t]{2}{*}{${ }^{1} \mathrm{H}(\mathrm{M}, \mathrm{J})$} & \multicolumn{3}{|c|}{${ }^{13} \mathrm{C}$} \\
\hline & & $\delta$ & DEPT 90 & DEPT 135 \\
\hline $\mathrm{CH}_{3}$ & $2.32(\mathrm{~s})$ & 33.39 & & $\left(\uparrow \mathrm{CH}_{3}\right)$ \\
\hline $\mathrm{C}^{\prime}, \mathrm{CH}_{2}$ & $2.25-2.29(\mathrm{~m}), 2.43-2.47(\mathrm{~m})$ & 54.31 & & $\left(\downarrow \mathrm{CH}_{2}\right)$ \\
\hline C9 & $4.47(d, 1.64)$ & 46.05 & $(\uparrow \mathrm{CH})$ & $(\uparrow \mathrm{CH})$ \\
\hline C10 & $4.29(t, 2.12)$ & 43.73 & $(\uparrow \mathrm{CH})$ & $(\uparrow \mathrm{CH})$ \\
\hline $\mathrm{C} 11, \mathrm{CH}_{2}$ & $1.25-1.28(\mathrm{~m}), 1.95-2.11(\mathrm{~m})$ & 33.02 & & $\left(\downarrow \mathrm{CH}_{2}\right)$ \\
\hline C12 & $2.25-2.29(\mathrm{~m})$ & 35.80 & $(\uparrow \mathrm{CH})$ & $(\uparrow \mathrm{CH})$ \\
\hline
\end{tabular}

Extension the Side Chain of the Aldehyde 2 via Wittig Reaction

The aldehyde 2 was subjected to Wittig olefination reaction employing two equivalent of the air stable stabilized commercially available Wittig reagent (Carbethoxymethylene) triphenylphosphorane (Scheme 2). The reaction was smoothly run at room temperature in dichloromethane $\left(\mathrm{CH}_{2} \mathrm{Cl}_{2}\right)$ to give $\mathrm{a}, \beta$ unsaturated ester $\mathbf{5}$ in $\mathbf{7 6} \%$ yield as a mixture of cis and trans isomers. The NMR J-coupling and chemical shift of the vinylic protons were recruited to differentiate between the cis and trans isomers. Based on the integration of the vinylic proton signals, the ratio of the cis and trans is approximately 1: 3.5 (Fig. S11a-c). The ${ }^{1} \mathrm{H}-\mathrm{NMR}$ spectrum of the trans isomer exhibited doublet signal at $\delta 5.78 \mathrm{ppm}$ with coupling constants $\mathrm{J}=25 \mathrm{~Hz}$ assigned for olefinic proton attached to $\mathrm{C}^{\prime} 2(-\mathrm{C}=\mathrm{CH}-\mathrm{COOEt})$ and a double doublet signal at $\delta 6.45 \mathrm{ppm}$ with coupling constant $\mathrm{J}=15,5 \mathrm{~Hz}$ assigned for olefinic proton attached to $\mathrm{C}^{\prime} 1$ (-CH = C-) (Fig. S11b). The IR spectrum of the unsaturated ester 5 displayed characteristic absorption of the enone system at $u 1650 \mathrm{~cm}^{-1}(C=C)$ together with the absorption peak of $(C=0)$ at $u 1709$ $\mathrm{cm}^{-1}$ 1(Fig. S12). For further structural elucidation of the compound 5 ; HSQC were run and presented in (Fig. S13). The a, $\beta$-unsaturated ester 5 , products of the Wittig reaction, was then subjected to selective hydrogenation to reduce $(C=C)$ double bond using palladium on carbon $(\mathrm{Pd} / \mathrm{C})$ as catalyst under $\mathrm{H}_{2}$ in ethanol at room temperature to afford the saturated ester 6 in a yield of $42 \%$. The NMR spectra of saturated ester $\mathbf{6}$ is clear where the signals of olefinic protons of the precursor $\mathbf{5}$ is disappeared and instead appearance of the triplet signal at $\delta 2.33 \mathrm{ppm}$ with coupling constant $\mathrm{J} 12 \mathrm{~Hz}$ assigned for the protons attached to the $\mathrm{C}^{\prime} 2\left(-\mathrm{CH}_{2}\right.$-COOEt) (Fig. S14). For further structural elucidation of the saturated ester 6; homonuclear correlation ${ }^{1} \mathrm{H}-{ }^{1} \mathrm{H}$ correlation, double-quantum filtered correlation spectroscopy (DQF-COSY) technique was employed to assign proton chemical shifts (Fig. S15), HSQC experiments were done to determine the protons attached to a specific carbon (Fig. S16) and high resolution mass spectroscopy (HRMS) to specify the molecular weight (Fig. S17). 


\section{Conformer Analysis}

Conformational analysis of the compound $\mathbf{2}$ revealed three minima and three transition states (Fig. 2). The absence of imaginary frequencies on the calculated vibrational spectrum confirms the global minimum energy for all the conformers. Different conformers of the compound $\mathbf{2}$ were found out by carrying out a potential energy scan about the $\mathrm{C}-\mathrm{C}$ bond connecting the aldehyde group $(\mathrm{CHO})$ to the fused ring structure. The relative energies $(\mathrm{kJ} / \mathrm{mol})$ of different conformations are tabulated (Table 2). The 2-C2 conformer is the most stable, which is lower in energy than the other two conformers 2-C1 and 2-C3 by $2.5205 \mathrm{~kJ} / \mathrm{mol}$ and $5.3035 \mathrm{~kJ} / \mathrm{mol}$, respectively (Fig. 3).

Table 2

Energies (a.u.) of the predicted conformations of the compound 2

\begin{tabular}{|llll|}
\hline Parameter & 2-C1 & 2-C2 & 2-C3 \\
\hline $\mathrm{E}_{\mathrm{Tot}}$ & -1650.88155 & -1650.88251 & -1650.88049 \\
\hline
\end{tabular}

The lower in energy of the 2-C2 conformer could result from the electrostatic interaction between the electropositive region or $\sigma$ hole of the chlorine atom, serves as a Lewis acid, and the carbonyl oxygen, serve as a Lewis base (Fig. 4) in analogous to a classic hydrogen bonding. This result is supported by the most "provisional recommendation" by IUPAC [25], which state that there is an interaction between a nucleophilic region of a carbonyl oxygen and an electrophilic region of a halogen atom.

\section{Conclusion}

The synthesis of 1,5-dichloroethanoanthracenes $(2,3,5,6)$ have been successfully done via multistep reactions involving Diels-Alder and Wittig reactions. In order to identify the structures of the newly synthesized compounds clearly; the structural elucidation techniques, including COSY, HSQC and HRMS were extensively employed. The DFT calculations and the experimentally found isomers of aldehyde 2 were in a good agreement. This study will pave the researchers to synthesize another 1,5dichloroethanoanthracenes and then explore their biological activities such as antidepressants, antimalarial agents and antiproliferative agents.

\section{Declarations}

\section{Acknowledgement}

The authors would like to extend their sincere appreciation to Taif University Researchers Supporting Project number (TURSP- 2020/136), Taif University, Taif, Saudi Arabia. RR also thanks to Dr. B. Harikumar, Former HOD, Department of Chemistry, T.K.M. College of Arts and Science, Kollam, Kerala, India for the providing computational support.

\section{Conflict of interest}


The authors declare that they have no conflict of interest.

\section{References}

1. Tosic O, Mattay J (2011) New photochromic dithienylethenes through a click chemistry approach. Wiley Online Library

2. Nguyen QPB, Kim J-N, Kim T-H (2009) Investigation of isomerism in anthracene-isothiouronium salts and application of these salts for anion sensing. Bull Korean Chem Soc 30(9):2093-2097

3. Langelaar J (1975) Use of time-resolved excited state spectroscopy for selection of laser dyes. Applied physics 6(1):61-64

4. Schäfer C, Strübe F, Bringmann S, Mattay J (2008) Photocyclizable resorcin [4] arene dimers. Photochem Photobiol Sci 7(12):1457-1462

5. Gassensmith JJ, Baumes JM, Eberhard J, Smith BD. Cycloaddition to an anthracene-derived macrocyclic receptor with supramolecular control of regioselectivity. Chemical communications. 2009(18):2517-9

6. Bringmann S, Ahmed SA, Hartmann R, Mattay J (2011) Synthesis of 1, 5-Substituted Anthracenes by Means of Kumada Coupling and Their Derivatization. Synthesis 2011(14):2291-2296

7. Beletskaya IP, Bessmertnykh AG, Averin AD, Denat F, Guilard R (2005) Palladium-Catalysed Amination of 1, 8-and 1, 5-Dichloroanthracenes and 1, 8-and 1,5-Dichloroanthraquinones. European journal of organic chemistry 2005(2):281-305

8. Ranyuk E, Averin A, Buryak A, Savel'ev E, Orlinson B, Novakov I et al (2009) Palladium-catalyzed amination in the synthesis of macrocyclic compounds containing 1, 3-disubstituted adamantane fragments. Russian journal of organic chemistry 45(10):1555-1566

9. Beletskaya IP, Averin AD (2004) Palladium-catalyzed arylation of linear and cyclic polyamines. Pure applied chemistry 76(9):1605-1619

10. Ma Y-X, Meng Z, Chen C-F (2015) Synthesis of Substituted Iptycenes Synlett 26(01):6-30

11. Mori I, Kadosaka T, Sakata Y, Misumi S (1971) Synthesis and spectral properties of chlorosubstituted triptycenes. Bull Chem Soc Jpn 44(6):1649-1652

12. Lamm J-H, Glatthor J, Weddeling J-H, Mix A, Chmiel J, Neumann B et al (2014)

Polyalkynylanthracenes-syntheses, structures and their behaviour towards UV irradiation. Org Biomol Chem 12(37):7355-7365

13. Muhammad H, Hanif M, Tahiri IA, Versiani MA, Shah F, Khaliq O et al (2018) Electrochemical behavior of superoxide anion radical towards quinones: a mechanistic approach. Res Chem Intermed 44(10):6387-6400

14. Chen RF, Shen YC, Huang HS, Liao JF, Ho LK, Chou YC et al (2004) Evaluation of the antiinflammatory and cytotoxic effects of anthraquinones and anthracenes derivatives in human leucocytes. J Pharm Pharmacol 56(7):915-919 
15. Chen R-F, Chou C-L, Wang M-R, Chen C-F, Liao J-F, Ho L-K et al (2004) Small-molecule anthraceneinduced cytotoxicity and induction of apoptosis through generation of reactive oxygen species. Biological Pharmaceutical Bulletin 27(6):838-845

16. Cloonan SM, Williams DC (2011) The antidepressants maprotiline and fluoxetine induce Type II autophagic cell death in drug-resistant Burkitt's lymphoma. Int J Cancer 128(7):1712-1723

17. McNamara Y, Bright S, Byrne A, Cloonan S, McCabe T, Williams D et al (2014) Synthesis and antiproliferative action of a novel series of maprotiline analogues. Eur J Med Chem 71:333-353

18. Wilhelm M, Schmidt P (1969) Synthese und Eigenschaften von 1-Aminoalkyl-dibenzo [b, e] bicyclo [2.2. 2] octadienen. Helv Chim Acta 52(6):1385-1395

19. Robichaud A, Ajjou AN (2006) First example of direct reductive amination of aldehydes with primary and secondary amines catalyzed by water-soluble transition metal catalysts. Tetrahedron Lett 47(22):3633-3636

20. Abdel-Magid AF, Carson KG, Harris BD, Maryanoff CA, Shah RD (1996) Reductive amination of aldehydes and ketones with sodium triacetoxyborohydride. Studies on direct and indirect reductive amination procedures1. The Journal of Organic Chemistry 61(11):3849-3862

21. Cho BT, Kang SK (2005) Direct and indirect reductive amination of aldehydes and ketones with solid acid-activated sodium borohydride under solvent-free conditions. Tetrahedron 61(24):5725-5734

22. Guyon C, Da Silva E, Lafon R, Métay E, Lemaire M (2015) Reductive amination using a combination of $\mathrm{CaH} 2$ and noble metal. RSC Advances 5(3):2292-2298

23. Heydari A, Arefi A, Esfandyari M (2007) Direct reductive amination of aldehydes and selective reduction of $a, \beta$-unsaturated carbonyl compounds by $\mathrm{NaBH} 4$ in the presence of guanidine hydrochloride in water. J Mol Catal A: Chem 274(1):169-172

24. Pisiewicz S, Stemmler T, Surkus AE, Junge K, Beller M (2015) Synthesis of Amines by Reductive Amination of Aldehydes and Ketones using $\mathrm{Co}_{3} \mathrm{O}_{4} / \mathrm{NGr@} \mathrm{C} \mathrm{Catalyst.} \mathrm{ChemCatChem} \mathrm{7(1):62-64}$

25. Kolář M, Hobza P, Bronowska AK (2013) Plugging the explicit o-holes in molecular docking. Chem Commun 49(10):981-983

26. Sanyal A. Chiral anthracenes as Diels-Alder/retro Diels-Alder templates in asymmetric synthesis. 2002

27. Karama U, Sultan MA, Almansour Al, El-Taher KE (2016) Synthesis of chlorinated tetracyclic compounds and testing for their potential antidepressant effect in mice. Molecules 21(1):61

28. Frisch MJ, Schlegel GWT,HB, Scuseria GE, Robb MA, Cheeseman JR, Scalmani G, Barone V, Mennucci B, Petersson GA, Nakatsuji H, Caricato M, Li X, Hratchian HP, Izmaylov AF, Bloino J, Zheng G, Sonnenberg JL, Hada M, Ehara M, Toyota K, Fukuda R, Hasegawa J, Ishida M, Nakajima T, Honda Y, Kitao O, Nakai H, Vreven T, Montgomery JA Jr, Peralta JE, Ogliaro F, Bearpark M, Heyd JJ, Brothers E, Kudin KN, Staroverov VN, Kobayashi R, Normand J, Raghavachari K, Rendell A, Burant JC, lyengar SS, Tomasi J, Cossi M, Rega N, Millam JM, Klene M, Knox JE, Cross JB, Bakken V, Adamo C, Jaramillo J, Gomperts R, Stratmann RE, Yazyev O, Austin AJ, Cammi R, Pomelli C, Ochterski JW, Martin RL, Morokuma K, Zakrzewski VG, Voth GA, Salvador P, J. J. Dannenberg S, Dapprich, A. D. 
Daniels, O. Farkas, J. B. Foresman, J. V. Ortiz, J. Cioslowski, D. J. Fox Gaussian, Inc., Wallingford CT, 2009. 2009

29. Beck AD (1993) Density-functional thermochemistry. III. The role of exact exchange. J Chem Phys 98(7):5648-5646

Figures

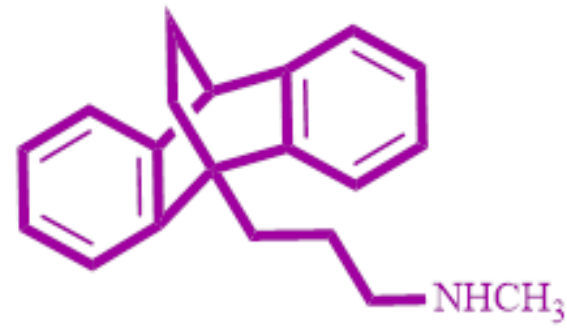

Maprotiline

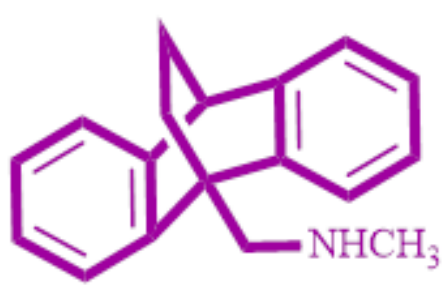

Benzoctamine

Figure 1

Structures of the Ethanoanthracenes Pharmaceutical Agents; Maprotiline and Benzoctamine
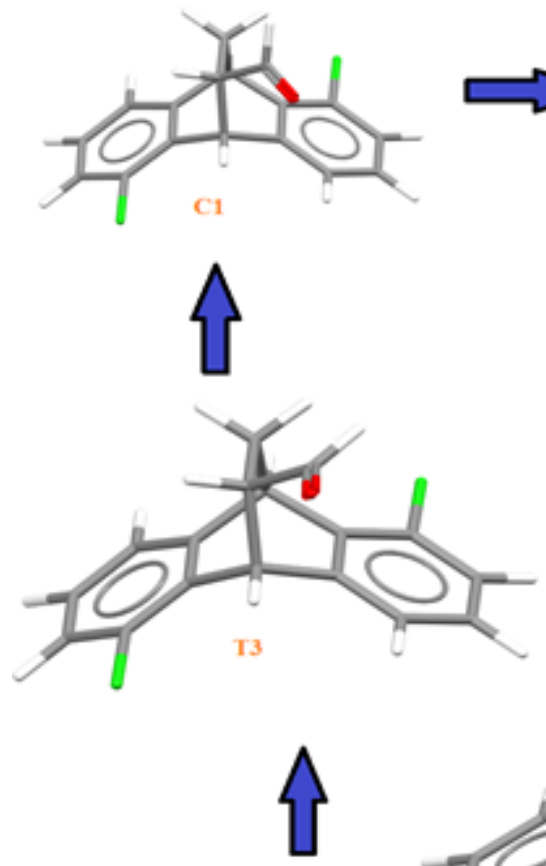
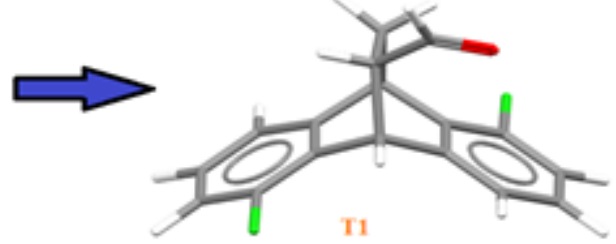

T1
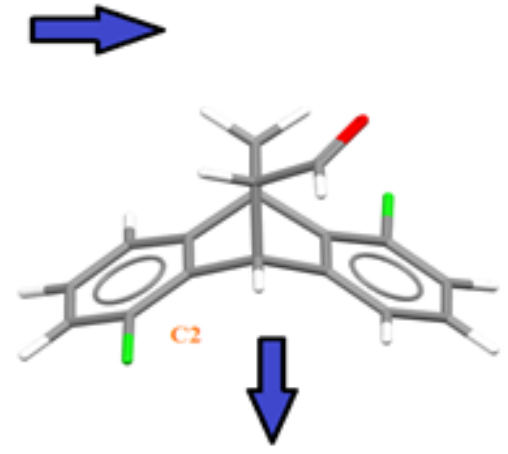

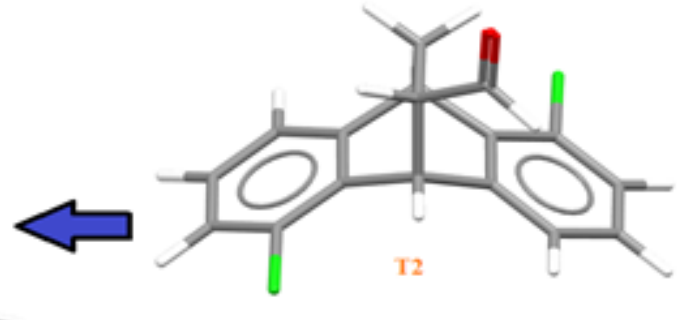

$\mathrm{C} 3$
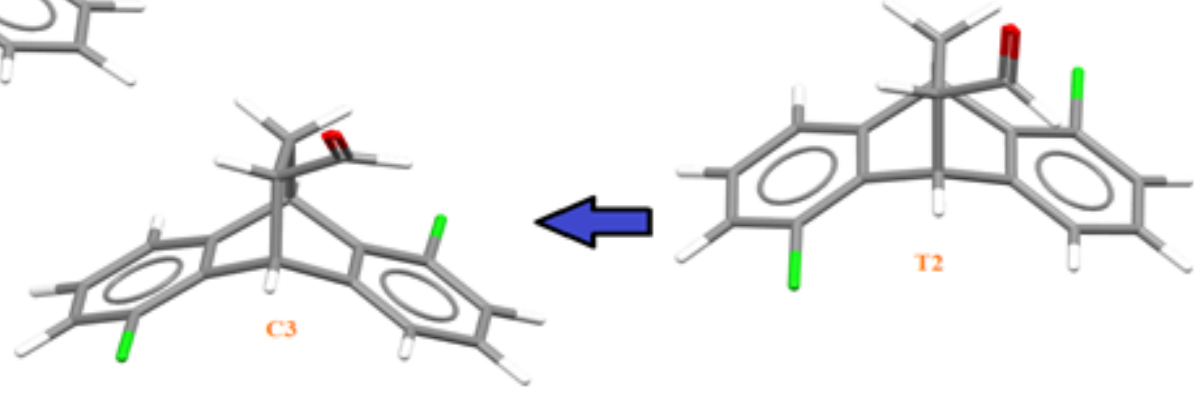

Figure 2

Conformational interconversion of the various minimum (C) and transition state $(T)$ conformers of the compound 2 

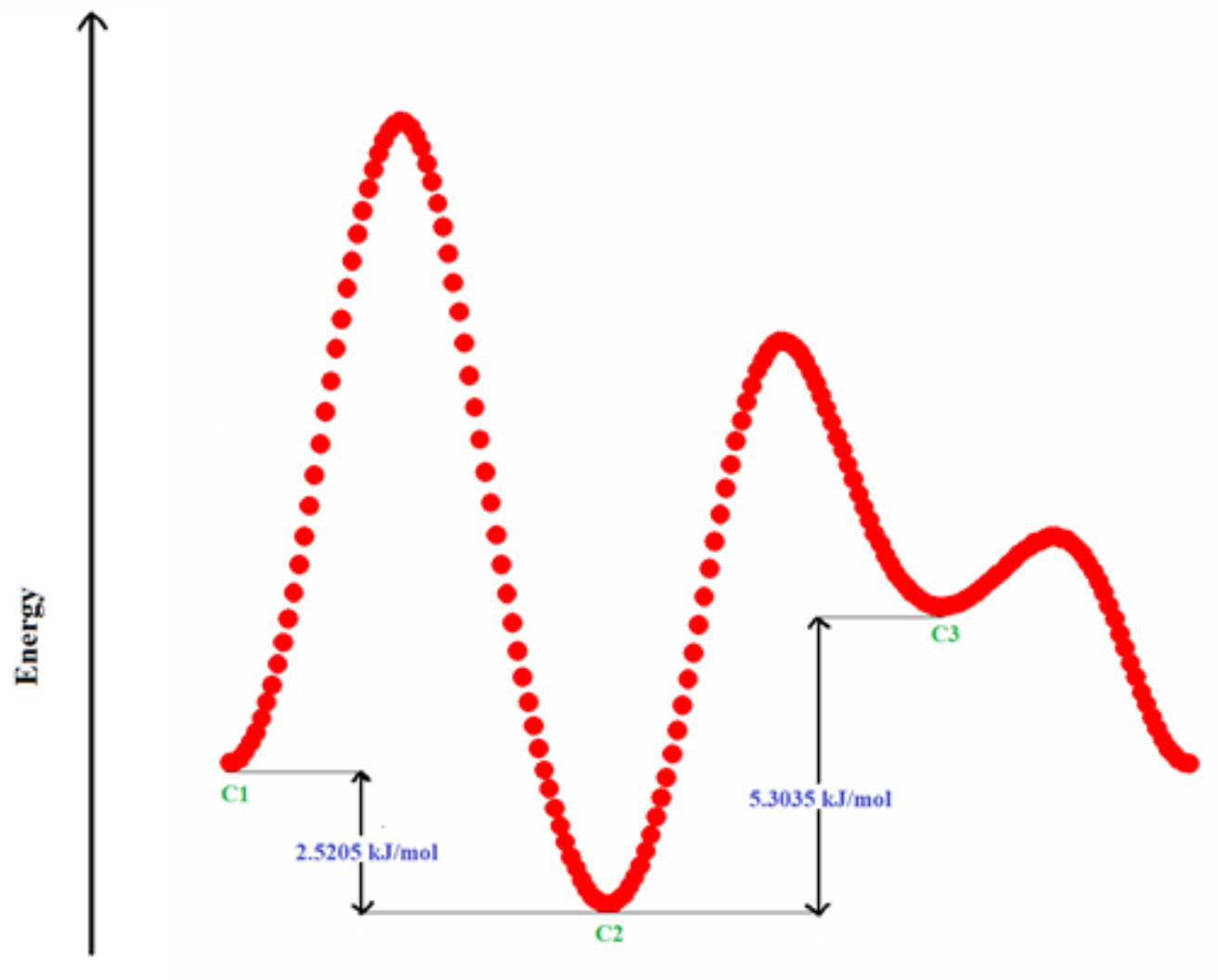

Figure 3

Potential Energy Scan profiles for the conformational interconversion of the conformers 2-C1, 2-C2 and 2C3.
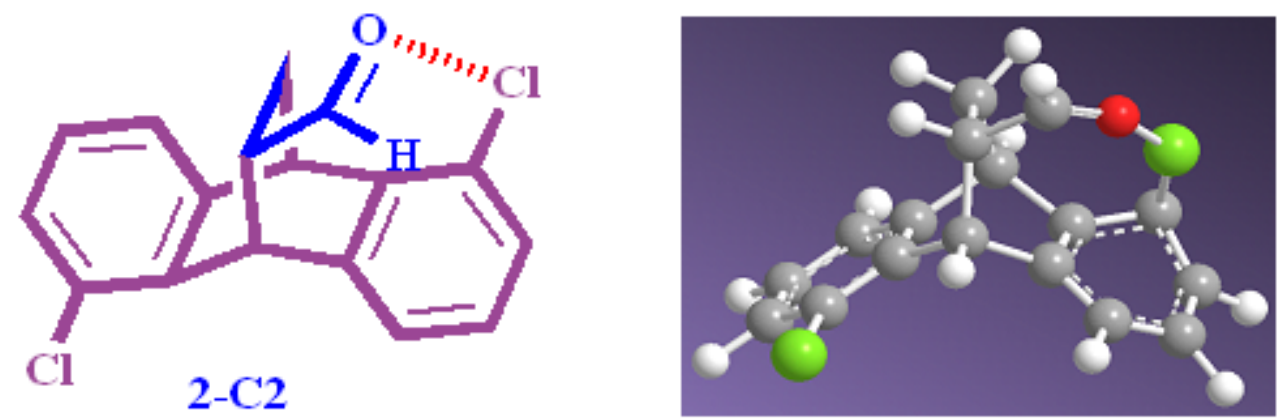

Figure 4

Plausible intramolecular interaction between chlorine $(\mathrm{Cl})$ and oxygen $(0)$ in 2-C2.

\section{Supplementary Files}

This is a list of supplementary files associated with this preprint. Click to download. 
- GA.png

- Scheme01.png

- Scheme02.png

- SupportingInformationManscript2242021.docx.docx 